\title{
Demonstration of a post-combustion carbon capture pilot plant using amine-based solvents at the Laziska Power Plant in Poland
}

\author{
Marcin Stec $^{1} \cdot$ Adam Tatarczuk $^{1} \cdot$ Lucyna Więcław-Solny $^{1} \cdot$ Aleksander Krótki $^{1}$ • \\ Tomasz Spietz $^{1} \cdot$ Andrzej Wilk $^{1} \cdot$ Dariusz Śpiewak $^{1}$
}

Received: 4 May 2015/Accepted: 15 June 2015/Published online: 28 June 2015

(c) The Author(s) 2015. This article is published with open access at Springerlink.com

\begin{abstract}
As a part of the strategic research program "Advanced technologies for energy generation: Development of a technology for highly efficient zero-emission coal-fired power units integrated with $\mathrm{CO}_{2}$ capture", a mobile $\mathrm{CO}_{2}$ absorption pilot plant was erected. The main purpose of the pilot plant was to demonstrate the postcombustion technology in conjunction with a coal-fired power plant. The pilot plant captured $\mathrm{CO}_{2}$ by chemical absorption in amine-based solvents, which was considered to be the best adapted technology to the requirements of coal-fired power plants and suitable for retrofitting to existing units. The pilot plant captured up to $1000 \mathrm{~kg} / \mathrm{day}$ of $\mathrm{CO}_{2}$ from the power plant's flue gases with $\mathrm{CO}_{2}$ recovery exceeding $90 \%$. The flexible process flowsheet of the pilot plant offered high potential for the validation of various improvements, which were designed to reduce the process energy demand and to increase the $\mathrm{CO}_{2}$ recovery. This paper summarizes the initial operation experience at the TAURON Łaziska Power Plant in Poland. Selected first results obtained are presented and discussed. The initial campaigns utilized 20 and $30 \mathrm{wt} \%$ monoethanolamine (MEA) solutions recognized as baseline solvents that were suitable for comparative purposes. The initial campaigns at the pilot plant successfully demonstrated reliable operation and promising results.
\end{abstract}

Keywords Carbon capture - Pilot plant - CCS . Post-combustion · MEA

Marcin Stec

mstec@ichpw.pl

1 Institute for Chemical Processing of Coal, Zamkowa 1, 41-803 Zabrze, Poland

\author{
Abbreviations \\ $\mathrm{HCl}$ Hydrochloric acid \\ $\mathrm{KOH}$ Potassium hydroxide \\ $L / G \quad$ Liquid-to-gas ratio $(\mathrm{kg} / \mathrm{kg})$ \\ $M \quad$ Molarity $\left(\mathrm{mol} / \mathrm{dm}^{3}\right)$ \\ MEA Monoethanolamine \\ $\alpha \quad$ Solvent loading $\left(\mathrm{mol}_{\mathrm{CO}_{2}} / \mathrm{mol}_{\mathrm{MEA}}\right)$ \\ $\Delta \alpha \quad$ Loading difference between rich and lean solvents \\ $\left(\mathrm{mol}_{\mathrm{CO}_{2}} / \mathrm{mol}_{\mathrm{MEA}}\right)$ \\ $\eta \quad \mathrm{CO}_{2}$ recovery (\%) \\ $C_{\mathrm{CO}_{2}}$ Carbon dioxide concentration in the flue gas \\ (vol\%) \\ $C_{\text {MEA }}$ Amine concentration (wt $\%$ ) \\ $E_{\mathrm{CO}_{2}} \quad$ Energy demand for solvent regeneration (MJ/ \\ $\mathrm{kg}_{\mathrm{CO}_{2}}$ ) \\ $G_{\text {AN }} \quad$ Rich amine flow rate $(\mathrm{kg} / \mathrm{h})$ \\ $H \quad$ Absorber height (m) \\ $P \quad$ Power delivered to the stripper $(\mathrm{kW})$ \\ $p_{\text {ABS }} \quad$ Absorber gauge pressure $(\mathrm{kPa})$ \\ $p_{\text {DES }} \quad$ Stripper gauge pressure $(\mathrm{kPa})$ \\ $t \quad$ Absorber temperature $\left({ }^{\circ} \mathrm{C}\right)$
}

\section{Introduction}

Topics related to greenhouse gas emissions have become important for the power generation sector due to climate change policy and the adoption of laws promoting reductions of greenhouse gas emissions in a cost-effective and economically efficient manner. Implementation of the greenhouse gas emission policies would cause increases in the price of energy due to high costs of carbon capture and storage (CCS) technologies. To reduce the negative impact of CCS on energy prices, new technologies that reduce the 
energy demand of the process have been extensively researched (Bandyopadhyay 2010; Damartzis et al. 2014) or alternative methods of $\mathrm{CO}_{2}$ emissions reduction have been analyzed (Maroušek et al. 2014). This paper addresses the presentation of a mobile amine carbon capture pilot plant. The mobile pilot plant was designed as a flexible unit that was suitable for the validation of flowsheets or solvent modifications and the investigation of the influence of different process variants on $\mathrm{CO}_{2}$ recovery and process energy demand.

The Institute for Chemical Processing of Coal in cooperation with industrial partners, TAURON Polska Energia S.A. and TAURON Wytwarzanie S.A., designed, erected, and operated the carbon capture pilot plant. The pilot plant was based on an amine post-combustion process and was designed as a mobile unit (Fig. 1), providing the opportunity to test the process in various locations.

The pilot plant consisted of three containers: technological, storage, and supervision. Containers, having typical dimensions, allowed fast shipment and installation. This flexibility of the mobile pilot plant allowed tests on different power plants or even on other sources of flue gases. The pilot plant provided the opportunity to test the deep desulfurization of flue gases and carbon dioxide capture using chemical absorption in an amine solution. The research has focused on the effects of the variation of the following parameters on the process: the pressure and temperature of absorption and desorption, L/G optimization, the influence of splitting of rich and lean amine solution streams, and inter-heating of the stripper.

In 2013, the pilot plant was transported and connected to TAURON's Łaziska Power Plant in Łaziska Górne, Poland, where, overall, $550 \mathrm{~h}$ of tests were conducted using a baseline solvent, monoethanolamine (MEA) solution (Krótki et al. 2014). More than $19,000 \mathrm{~kg}$ of $\mathrm{CO}_{2}$ was captured during the campaigns. In this article, selected results from tests verifying plant functionality in the basic process configuration (no streams split) are summarized. In addition to the results, the test procedures and analytical methods utilized are presented.

\section{$\mathrm{CO}_{2}$ absorption pilot plant}

\section{Process description}

The pilot plant was connected to a 225 MWe hard coalfired boiler at the Łaziska Power Plant in Łaziska Górne, Poland. The flue gas stream was extracted downstream of the power plant's desulphurization unit. The typical flue gas parameters were as follows: flue gas flow, $200 \mathrm{~m}^{3} \mathrm{~N} / \mathrm{h}$; $\mathrm{CO}_{2}$ content, 11-13 vol\%; $\mathrm{SO}_{2}$ content, max. $200 \mathrm{mg} / \mathrm{m}^{3}$; temperature, up to $99^{\circ} \mathrm{C}$; and pressure, atmospheric.

The flue gas was cooled and dedusted in a direct water scrubber and sweetened in a desulfurization column where $\mathrm{SO}_{2}$ was removed (deep desulfurization unit). The solvent used for desulfurization contained sodium bicarbonate and maintained the $\mathrm{SO}_{2}$ concentration in the flue gas below $20 \mathrm{mg} / \mathrm{m}^{3}$ to avoid solvent degradation and to decrease the corrosivity of the solution (Zhou et al. 2013). Next, the gas entered the absorber bottom and flowed upward through the packing where the $\mathrm{CO}_{2}$ chemically reacted with lean amine solution to remove most of the $\mathrm{CO}_{2}$. Tables 1 and 2 provide information on the columns used in the pilot plant, including the packing materials.

The treated gas was passed through a water wash at the absorber top to cool and separate excess water and then was vented through the top of the absorber and back to the power plant stack. A low amount of fresh water is added into the washing water recycle stream to avoid a prohibitive accumulation of amine in the washing section and to compensate water losses.
Fig. 1 Carbon capture pilot plant during tests at the Łaziska Power Plant in Łaziska Górne, Poland

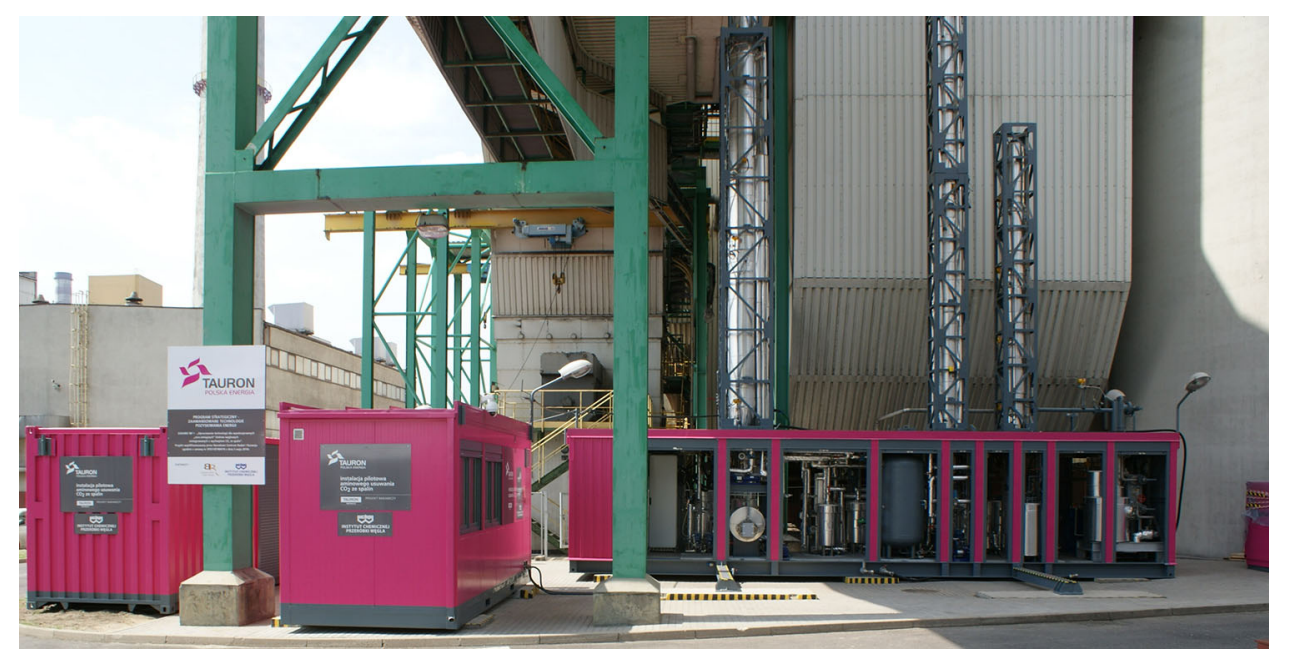


Table 1 Overview of process parameters analyzed in this paper

Table 2 Column size, packing heights, and packing elements at the mobile pilot plant

\begin{tabular}{|c|c|c|c|}
\hline \multicolumn{3}{|l|}{ Parameter } & \multirow[t]{2}{*}{ Range of variations } \\
\hline Symbol & \multicolumn{2}{|l|}{ Description } & \\
\hline $\mathrm{C}_{\mathrm{CO}_{2}}$ & \multicolumn{2}{|c|}{ Carbon dioxide concentration in flue gas } & $9.0-13.0(\%$ vol $)$ \\
\hline$L / G$ & \multicolumn{2}{|c|}{ Liquid-to-gas flow ratio } & $2.7-5.4(\mathrm{~kg} / \mathrm{kg})$ \\
\hline$G_{\mathrm{AN}}$ & \multicolumn{2}{|c|}{ Rich amine solution flow } & 800-1600 (kg/h) \\
\hline$C_{\mathrm{MEA}}$ & \multicolumn{2}{|c|}{ Amine concentration } & $20-35(\%)$ \\
\hline$p_{\mathrm{ABS}}$ & \multicolumn{2}{|l|}{ Absorber pressure } & $25-35(\mathrm{kPa})$ \\
\hline$p_{\mathrm{DES}}$ & \multicolumn{2}{|l|}{ Stripper pressure } & $30-40(\mathrm{kPa})$ \\
\hline$\eta$ & \multicolumn{2}{|l|}{$\mathrm{CO}_{2}$ recovery } & $60.0-99.7(\%)$ \\
\hline$E_{\mathrm{CO}_{2}}$ & \multicolumn{2}{|c|}{ Energy demand for solvent regeneration } & $3.39-5.07\left(\mathrm{MJ} / \mathrm{kg}_{\mathrm{CO}_{2}}\right)$ \\
\hline Column & Diameter (mm) & Packing height $(\mathrm{mm})$ & Packing element \\
\hline \multirow[t]{3}{*}{ Deep desulphurization } & \multirow[t]{3}{*}{330} & 800 & Sulzer CY \\
\hline & & 1600 & Sulzer Mellapak 750Y \\
\hline & & 900 & Sulzer P-Ring 5/8" \\
\hline \multirow[t]{3}{*}{ Absorber } & \multirow[t]{3}{*}{330} & 800 & Sulzer Mellapak 750Y \\
\hline & & 3300 & Sulzer Mellapak 500Y \\
\hline & & 5100 & Sulzer Mellapak 350Y \\
\hline \multirow[t]{6}{*}{ Stripper } & 280 & 800 & Sulzer Mellapak 750Y \\
\hline & 280 & 1000 & Sulzer Mellapak 750Y \\
\hline & 280 & 1000 & Sulzer Mellapak 750Y \\
\hline & 510 & 5000 & Sulzer C-Ring 1" \\
\hline & \multirow[t]{2}{*}{280} & 1400 & (within the internal heat exchanger) \\
\hline & & & Sulzer Mellapak 750Y \\
\hline
\end{tabular}

The packing elements enumerated from top to bottom of the columns

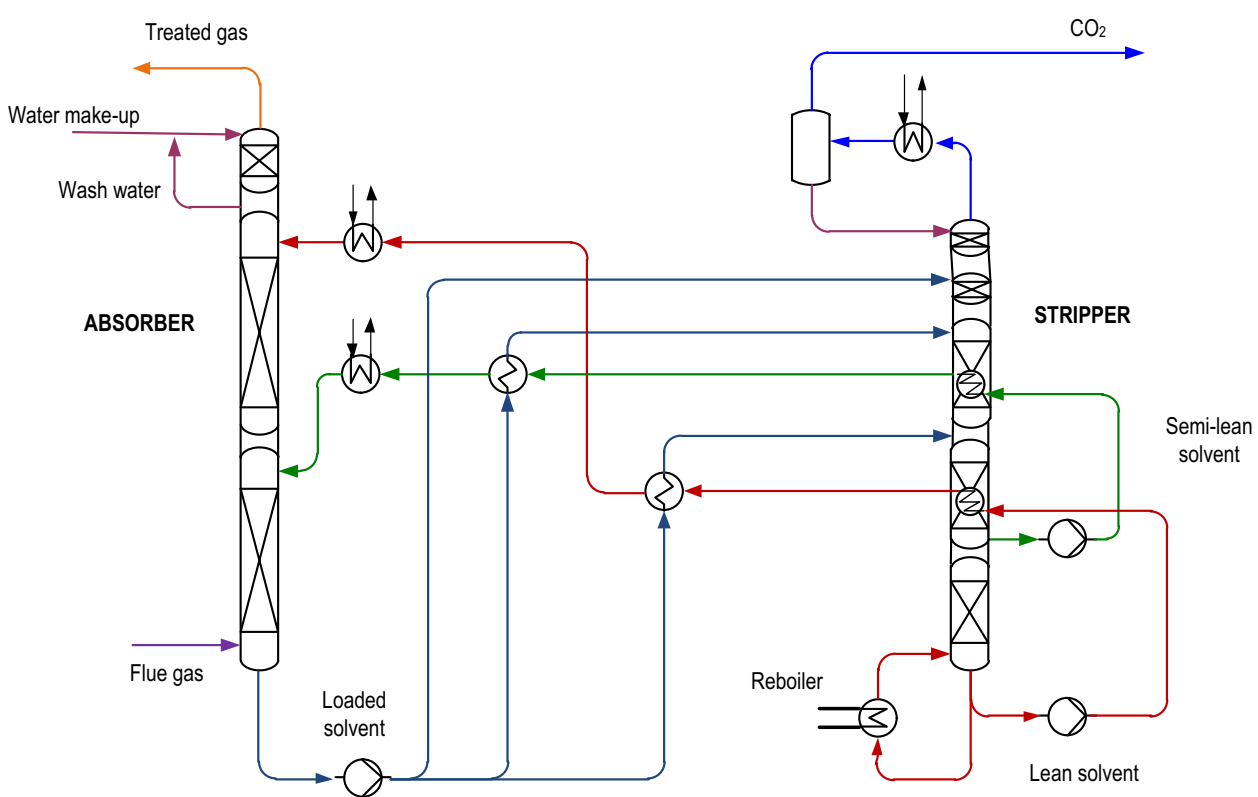

Fig. 2 Process flow diagram of the carbon capture unit of the pilot plant (Szczypiński et al. 2013)
The plant provides a possibility of solvent stream splitting (Fig. 2); however, the tests presented in this paper were conducted in the basic configuration and the semilean solvent line was not used.
A rich amine solution is pumped from the bottom of the absorber into the stripper through rich lean heat exchanger, allowing heat transfer from the hot lean solution to the colder rich solution. The lean solution was pumped back to 
the absorber, and during heat transfer it was cooled to $40{ }^{\circ} \mathrm{C}$ and filtered. In Fig. 2 additional line of rich solvent, bypassing heat exchangers, can be noticed. Using this line, small portion of rich solvent remains unheated and enters the top of the stripper. This stream is heated by condensing steam in the column which would normally be lost from the stripper. Reducing the losses of the steam and heating of a portion of amine reduce the overall energy requirements of the process. The flow rate of the unheated rich solvent was held constant at $100 \mathrm{dm}^{3} / \mathrm{h}$ during the operation.

The bottom of the stripper had built-in electrical heating elements for evaporation of the solvent. Hot solvent vapors were used for the regeneration and separation of the $\mathrm{CO}_{2}$ from the rich amine. Hot gases (containing mainly water vapors and $\mathrm{CO}_{2}$ ) leaving the stripping section entered the condenser section at the top of the column where part of the water was removed. An additional condenser downstream of the column was installed where the remaining portion of water was removed and almost pure $\mathrm{CO}_{2}$ was obtained. To intensify the amine regeneration process, the mobile pilot plant stripper had two additional build-in heat exchangers for inter-heating in the stripper. The application of the internal heat exchanger was default in the pilot plant; therefore, it was always operating during the tests presented in this paper. For a more detailed description of the pilot plant and its operation, see Tatarczuk et al. (2013) and Stec et al. (2015).

\section{Analytics}

During the test campaigns, typical solvent analysis was performed on site in a laboratory section that was separated from the supervision container. The most important parameters, such as the $\mathrm{pH}$ of the desulfurization solution and the $\mathrm{CO}_{2}$ concentration in the gas, were monitored online.

The quality of the desulfurization solution was measured by means of $\mathrm{pH}$ meters located downstream of the pumps that circulated the solution. If the $\mathrm{pH}$ of the solvent fell below 6, it was replaced to guarantee that the $\mathrm{SO}_{2}$ concentration in the gas entering the absorber was below $20 \mathrm{mg} / \mathrm{m}^{3}$ to avoid amine solvent degradation.

Gas samples were taken continuously during the operation of the pilot plant. Gas sampling probes were installed downstream and upstream of the desulfurization columns of the absorber and of the stripper. Additionally, the gas was sampled in the middle of the absorber's height. The gas samples were transferred to Siemens Ultramat 23 analyzers to measure the concentrations of $\mathrm{CO}_{2}, \mathrm{SO}_{2}, \mathrm{NO}_{2}$ or $\mathrm{NO}$, and $\mathrm{O}_{2}$. The analyzers simultaneously measured $\mathrm{CO}_{2}, \mathrm{SO}_{2}, \mathrm{NO}_{2}$, or $\mathrm{NO}$ with infrared detection and $\mathrm{O}_{2}$ with an electrochemical oxygen-measuring cell. The measurements of the $\mathrm{CO}_{2}$ concentration downstream and upstream of the absorption column were the most important and allowed for the calculation of $\mathrm{CO}_{2}$ recovery.

Acid-base titration was used to check the monoethanolamine (MEA) concentration in the solvent (Hartono et al. 2013). The solvent sample was titrated with $2 \mathrm{M}$ hydrochloric acid $(\mathrm{HCl})$, and the $\mathrm{pH}$ of the solution was continuously monitored during titration. The titration was straightforward because one mole of hydrochloric acid reacted with one mole of monoethanolamine, and one mole of amine salt was created. The titration end point occurred at $\mathrm{pH}$ 3.4-3.8 for a $30 \mathrm{wt} \%$ aqueous MEA solution. A WTW Profi Line $\mathrm{pH} 3110 \mathrm{pH}$ meter was used during the titration procedure. The hydrochloric acid was standardized by titration against a standard solution of potassium hydroxide $(\mathrm{KOH})$.

The $\mathrm{CO}_{2}$ loading of the solution was estimated from the density change. If the temperature and concentration of amine in sorbent are constant, the density of the solution depends only on the content of dissolved $\mathrm{CO}_{2}$. Hence, if the density of a sample is known, $\mathrm{CO}_{2}$ loading can be determined based on a known standardization curve (Hartono et al. 2014).

\section{Operation experience and results}

\section{Methodology of experiments}

Within 2013, over $550 \mathrm{~h}$ of tests were conducted at the pilot plant. The activities at the pilot plant were divided into the following major tasks:

- May 2013 - startup of the pilot plant,

- June 2013-July 2013-plant tuning and initial tests, and

- August 2013-November 2013-significant test campaigns.

Each test campaign lasted approximately $100 \mathrm{~h}$ of continuous operation. The campaigns were divided into shorter periods during which the influence of different process parameters was investigated. Changing the process parameters caused serious disturbances; therefore, it was very important to allow the plant to reach steady state. The analyses presented in this paper were carefully selected from a database of trends registered in the supervisory control and data acquisition (SCADA) system. The tests were recognized as valuable when the steady-state period lasted at least $2 \mathrm{~h}$. For balancing or performance estimation, the average of each parameter from the steady-state period was used for further calculations.

Unlike in the laboratory tests, the number of parameters influencing the process at the pilot plant was considerable. Therefore, comparing the tests is challenging. The authors decided not to analyze every test separately but to 
emphasize the common dependencies for each test. This approach seemed reasonable for industrial-like processes where changes in parameters having serious impacts on the process (such as the $\mathrm{CO}_{2}$ concentration in the flue gas) must be treated as disturbances. A summary of the process parameters of pilot plant tests presented in this paper is provided in Table 3. A more detailed analysis of the results is presented in subsequent sections.

\section{Temperature and $\mathrm{CO}_{2}$ concentration profiles}

Figure 3 shows temperature and $\mathrm{CO}_{2}$ concentration profiles as a function of the packing height of the absorber. The experiments were conducted with the basic process configuration (no streams split) at an L/G ratio of 4.6 for test 20 and 3.9 for test 2. Approximately $215 \mathrm{~m}^{3} \mathrm{~N} / \mathrm{h}$ of flue gases were treated in the pilot plant to achieve a $\mathrm{CO}_{2}$ recovery of $84.4 \%$ (test 20) and $92.5 \%$ (test 2). Remaining process parameters for the tests are summarized in Table 3. The lean solution that entered the absorber was cooled to $40{ }^{\circ} \mathrm{C}$ during both tests, and the highest temperature in absorber (the temperature bulge) reached approximately 60 and $75{ }^{\circ} \mathrm{C}$ for tests 20 and 2, respectively. As the $\mathrm{CO}_{2}$ was absorbed in the solvent, the temperature in the incoming solvent increased (Kvamsdal and Rochelle 2008). The temperature increase clearly indicated the exothermic effect of $\mathrm{CO}_{2}$ absorption with MEA. The colder lean solvent that entered the column in the upper part caused water condensation. The resulting temperature profiles along the column showed a pronounced bulge. The higher magnitude of the temperature bulge in case of test 2 could be explained by the higher amount of $\mathrm{CO}_{2}$ absorbed and slightly lower solvent-to-gas ratio in comparison to the test 20. The profiles were in accordance with the results shown by Mangalapally et al. (2012).

In addition to the colder lean solvent, the temperature decrease at the top of the absorber was caused by the water wash. The treated gas that left the absorber was cooled to avoid excessive water loss, which could cause amine buildup. Despite this cooling, due to the high vapor pressure of water compared with the amine, the water losses were unavoidable. Therefore, water was necessarily added to the wash section of the absorber to stabilize the amine concentration. The water make-up flow rates are included in Table 3.

\section{Solution loading}

The amount of $\mathrm{CO}_{2}$ dissolved in the solution was characterized by the solution loading $(\alpha)$ expressed as the ratio of the number of moles of $\mathrm{CO}_{2}$ present in the solvent to the number of moles of amine in the solvent. Figure 4 shows the rich and lean solution loading as a function of $\mathrm{CO}_{2}$ recovery for the selected tests having $L / G=5.3$. As shown in the figure, the average rich solvent loading was approximately $0.45 \mathrm{~mol}_{\mathrm{CO}_{2}} / \mathrm{mol}_{\mathrm{MEA}}$, and the average lean solvent loading was $0.27 \mathrm{~mol}_{\mathrm{CO}_{2}} / \mathrm{mol}_{\mathrm{MEA}}$. These values were considered the most suitable for monoethanolaminebased solvents according to the optimization performed by Abu-Zahra et al. (2007).

Figure 4 also shows the loading difference between the rich and lean amine solvents ( $\Delta \alpha$, cyclic capacity), which provided information regarding the utilization of the solvent. The tests, simultaneously having the highest $\mathrm{CO}_{2}$ recovery $(\eta)$, had the biggest loading difference between the rich and lean solvents $(\Delta \alpha)$ (Mangalapally et al. 2009).

The loading difference between the rich and lean amine solvents was also a measure of the regeneration of the solvent, which is shown in Fig. 5. Increasing the solvent flow rate $\left(G_{\mathrm{AN}}\right)$ while maintaining the stripper power $(P)$ constant reduced the period during which the solution remained in the stripper and led to lower regeneration and to a lower loading difference between the rich and lean solvents.

\section{$\mathrm{CO}_{2}$ recovery}

In addition to the regeneration energy demand, $\mathrm{CO}_{2}$ recovery is the most important indicator of process efficiency (SkorekOsikowska et al. 2012). The basic method to adjust $\mathrm{CO}_{2}$ recovery relies on controlling the power delivered to the heating elements in the stripper. Figure 6 shows the dependency of $\mathrm{CO}_{2}$ recovery as a function of the power delivered. Figure 6 also indicates higher energy demand for the solution having a lower MEA concentration (Kim et al. 2011). This behavior could be explained by comparing the amounts of amine and water in the solution. For the solvent having a higher amine concentration, the energy contribution needed to heat the water to the regeneration energy was lower. Due to this phenomenon, the energy contribution used for $\mathrm{CO}_{2}$ desorption could be higher, which resulted in better regeneration of the solvent (Meldon 2011).

It is worth noting that the $\mathrm{CO}_{2}$ recovery was highly dependent on different process factors such as the solvent flow rate, flue gas flow rate, $\mathrm{CO}_{2}$ partial pressure in the flue gas, process temperature, or process configuration (Cousins et al. 2011). Figure 6 clearly shows that the $\mathrm{CO}_{2}$ recovery could change up to $20 \%$ for constant energy delivered to the stripper, depending on the listed factors. This result showed that operating the process in optimal conditions could lead to serious energy savings.

\section{Effect of the absorber pressure}

Increasing the absorber pressure led to increased $\mathrm{CO}_{2}$ partial pressure, which was desirable because of the higher solubility of $\mathrm{CO}_{2}$ in the solvent (Wilk et al. 2013a). Figure 7 
Table 3 Summary of the process parameters for the presented pilot plant tests

\begin{tabular}{|c|c|c|c|c|c|c|c|c|c|}
\hline \multirow[t]{2}{*}{$\mathrm{Id}$} & \multirow{2}{*}{$\begin{array}{l}\text { MEA } \\
\text { fraction } \\
(\mathrm{wt} \%)\end{array}$} & \multirow[t]{2}{*}{$\begin{array}{l}\text { Flue gas } \\
\text { load }(\mathrm{kg} / \mathrm{h})\end{array}$} & \multirow[t]{2}{*}{$\begin{array}{l}\mathrm{CO}_{2} \text { concentration in } \\
\text { flue gas }(\% \mathrm{vol})\end{array}$} & \multirow[t]{2}{*}{$\begin{array}{l}\text { Reboiler heat duty } \\
\left(\mathrm{MJ} / \mathrm{kg}_{\mathrm{CO}_{2}}\right)\end{array}$} & \multirow{2}{*}{$\begin{array}{l}\mathrm{CO}_{2} \\
\text { recovery } \\
(\%)\end{array}$} & \multirow[t]{2}{*}{$\begin{array}{l}\mathrm{L} / \mathrm{G} \\
(\mathrm{kg} / \mathrm{kg})\end{array}$} & \multirow[t]{2}{*}{$\begin{array}{l}\text { Water make- } \\
\text { up }(\mathrm{kg} / \mathrm{h})\end{array}$} & \multicolumn{2}{|c|}{$\begin{array}{l}\text { Loading } \\
\left(\mathrm{mol}_{\mathrm{CO}_{2}} / \mathrm{mol}_{\mathrm{MEA}}\right.\end{array}$} \\
\hline & & & & & & & & Rich & Lean \\
\hline 1 & 30 & 287.6 & 12.35 & 3.88 & 91.1 & 3.9 & 6.9 & 0.44 & 0.27 \\
\hline 2 & 30 & 287.2 & 12.44 & 3.86 & 92.5 & 3.9 & 6.6 & 0.43 & 0.27 \\
\hline 3 & 30 & 290.2 & 12.74 & 4.03 & 86.2 & 3.9 & 6.0 & 0.44 & 0.28 \\
\hline 4 & 30 & 288.6 & 11.34 & 3.39 & 57.7 & 4.0 & 2.1 & 0.43 & 0.35 \\
\hline 5 & 30 & 291.8 & 12.20 & 3.60 & 80.9 & 3.9 & 2.1 & 0.44 & 0.29 \\
\hline 6 & 30 & 291.2 & 12.04 & 3.65 & 81.4 & 4.7 & 2.1 & 0.44 & 0.32 \\
\hline 7 & 30 & 289.6 & 12.10 & 3.77 & 89.4 & 4.7 & 2.1 & 0.43 & 0.30 \\
\hline 8 & 30 & 289.4 & 12.08 & 3.58 & 91.6 & 5.4 & 2.1 & 0.43 & 0.31 \\
\hline 9 & 30 & 288.2 & 11.11 & 3.83 & 99.7 & 5.4 & 2.1 & 0.42 & 0.30 \\
\hline 10 & 30 & 304.3 & 10.83 & 3.69 & 84.4 & 3.7 & 2.1 & 0.43 & 0.28 \\
\hline 11 & 30 & 290.3 & 11.05 & 3.70 & 88.3 & 3.9 & 2.1 & 0.43 & 0.28 \\
\hline 12 & 30 & 261.3 & 11.06 & 3.64 & 93.6 & 4.3 & 2.1 & 0.42 & 0.28 \\
\hline 13 & 30 & 291.0 & 12.54 & 4.05 & 84.3 & 2.7 & 8.0 & 0.47 & 0.25 \\
\hline 14 & 30 & 290.0 & 11.02 & 4.01 & 97.2 & 3.3 & 10.6 & 0.45 & 0.26 \\
\hline 15 & 30 & 291.0 & 11.15 & 3.91 & 95.9 & 3.3 & 11.0 & 0.46 & 0.27 \\
\hline 16 & 30 & 291.5 & 11.16 & 3.77 & 94.6 & 3.3 & 11.5 & 0.46 & 0.28 \\
\hline 17 & 30 & 291.3 & 12.29 & 3.84 & 89.8 & 3.2 & 7.0 & 0.45 & 0.25 \\
\hline 18 & 30 & 292.7 & 12.35 & 3.68 & 93.8 & 4.6 & 4.6 & 0.44 & 0.29 \\
\hline 19 & 30 & 292.2 & 11.26 & 3.80 & 91.4 & 4.6 & 2.1 & 0.44 & 0.30 \\
\hline 20 & 30 & 293.1 & 11.21 & 3.90 & 84.4 & 4.6 & 4.6 & 0.44 & 0.32 \\
\hline 21 & 30 & 297.8 & 12.78 & 3.62 & 84.2 & 5.3 & 2.6 & 0.43 & 0.32 \\
\hline 22 & 30 & 288.9 & 11.53 & 3.89 & 94.1 & 3.9 & 6.8 & 0.44 & 0.28 \\
\hline 23 & 30 & 289.0 & 9.89 & 4.34 & 95.2 & 3.9 & 6.8 & 0.41 & 0.26 \\
\hline 24 & 30 & 292.5 & 12.21 & 3.98 & 87.3 & 3.9 & 4.2 & 0.44 & 0.27 \\
\hline 25 & 30 & 291.8 & 12.17 & 3.86 & 89.5 & 3.9 & 10.9 & 0.44 & 0.27 \\
\hline 26 & 30 & 291.2 & 12.43 & 3.86 & 75.5 & 5.4 & 7.5 & 0.46 & 0.36 \\
\hline 27 & 30 & 290.1 & 12.43 & 3.79 & 76.7 & 3.9 & 6.4 & 0.46 & 0.32 \\
\hline 28 & 30 & 289.7 & 11.80 & 3.77 & 81.6 & 3.9 & 6.9 & 0.46 & 0.31 \\
\hline 29 & 30 & 289.7 & 12.54 & 3.71 & 78.6 & 2.7 & 8.1 & 0.47 & 0.26 \\
\hline 30 & 30 & 290.0 & 11.39 & 3.76 & 83.4 & 2.7 & 8.1 & 0.47 & 0.26 \\
\hline 31 & 30 & 291.7 & 11.30 & 3.95 & 88.6 & 2.7 & 8.1 & 0.47 & 0.25 \\
\hline 32 & 30 & 290.5 & 11.77 & 3.83 & 96.3 & 5.3 & 2.1 & 0.42 & 0.30 \\
\hline 33 & 30 & 289.7 & 11.66 & 3.64 & 94.2 & 5.3 & 2.1 & 0.42 & 0.30 \\
\hline 34 & 30 & 293.5 & 12.19 & 3.65 & 89.7 & 5.3 & 2.1 & 0.42 & 0.30 \\
\hline 35 & 30 & 293.4 & 12.22 & 3.75 & 82.6 & 5.3 & 2.1 & 0.42 & 0.31 \\
\hline 36 & 30 & 287.9 & 12.42 & 3.81 & 81.3 & 5.4 & 2.1 & 0.41 & 0.31 \\
\hline 37 & 30 & 302.6 & 11.72 & 3.81 & 80.5 & 5.2 & 2.1 & 0.42 & 0.31 \\
\hline 38 & 30 & 291.6 & 11.65 & 3.80 & 85.7 & 5.3 & 2.1 & 0.42 & 0.31 \\
\hline 39 & 30 & 290.6 & 11.77 & 3.72 & 86.0 & 5.3 & 2.1 & 0.41 & 0.30 \\
\hline 40 & 30 & 288.4 & 12.11 & 3.94 & 80.5 & 5.4 & 2.1 & 0.41 & 0.31 \\
\hline 41 & 30 & 292.2 & 10.43 & 3.99 & 90.7 & 5.3 & 2.1 & 0.40 & 0.29 \\
\hline 42 & 30 & 291.6 & 10.40 & 3.87 & 93.2 & 5.3 & 2.1 & 0.40 & 0.30 \\
\hline 43 & 30 & 291.8 & 10.47 & 3.86 & 91.4 & 5.3 & 2.8 & 0.40 & 0.30 \\
\hline 44 & 30 & 292.4 & 10.42 & 3.95 & 90.2 & 5.3 & 2.7 & 0.40 & 0.30 \\
\hline 45 & 20 & 292.3 & 10.36 & 4.68 & 96.0 & 5.2 & 2.1 & - & - \\
\hline 46 & 20 & 291.3 & 9.81 & 4.57 & 95.5 & 5.2 & 3.6 & - & - \\
\hline
\end{tabular}


Table 3 continued

\begin{tabular}{|c|c|c|c|c|c|c|c|c|c|}
\hline \multirow[t]{2}{*}{ Id } & \multirow{2}{*}{$\begin{array}{l}\text { MEA } \\
\text { fraction } \\
(\mathrm{wt} \%)\end{array}$} & \multirow[t]{2}{*}{$\begin{array}{l}\text { Flue gas } \\
\text { load }(\mathrm{kg} / \mathrm{h})\end{array}$} & \multirow[t]{2}{*}{$\begin{array}{l}\mathrm{CO}_{2} \text { concentration in } \\
\text { flue gas }(\% \mathrm{vol})\end{array}$} & \multirow[t]{2}{*}{$\begin{array}{l}\text { Reboiler heat duty } \\
\left(\mathrm{MJ} / \mathrm{kg}_{\mathrm{CO}_{2}}\right)\end{array}$} & \multirow{2}{*}{$\begin{array}{l}\mathrm{CO}_{2} \\
\text { recovery } \\
(\%)\end{array}$} & \multirow[t]{2}{*}{$\begin{array}{l}\mathrm{L} / \mathrm{G} \\
(\mathrm{kg} / \mathrm{kg})\end{array}$} & \multirow[t]{2}{*}{$\begin{array}{l}\text { Water make- } \\
\text { up }(\mathrm{kg} / \mathrm{h})\end{array}$} & \multicolumn{2}{|c|}{$\begin{array}{l}\text { Loading } \\
\left(\mathrm{mol}_{\mathrm{CO}_{2}} / \mathrm{mol}_{\mathrm{MEA}}\right)\end{array}$} \\
\hline & & & & & & & & Rich & Lean \\
\hline 47 & 20 & 289.2 & 9.72 & 4.63 & 95.0 & 5.2 & 6.4 & - & - \\
\hline 48 & 20 & 291.9 & 10.89 & 4.76 & 82.1 & 5.2 & 3.0 & - & - \\
\hline 49 & 20 & 282.6 & 10.07 & 5.07 & 85.9 & 5.4 & 5.9 & - & - \\
\hline
\end{tabular}
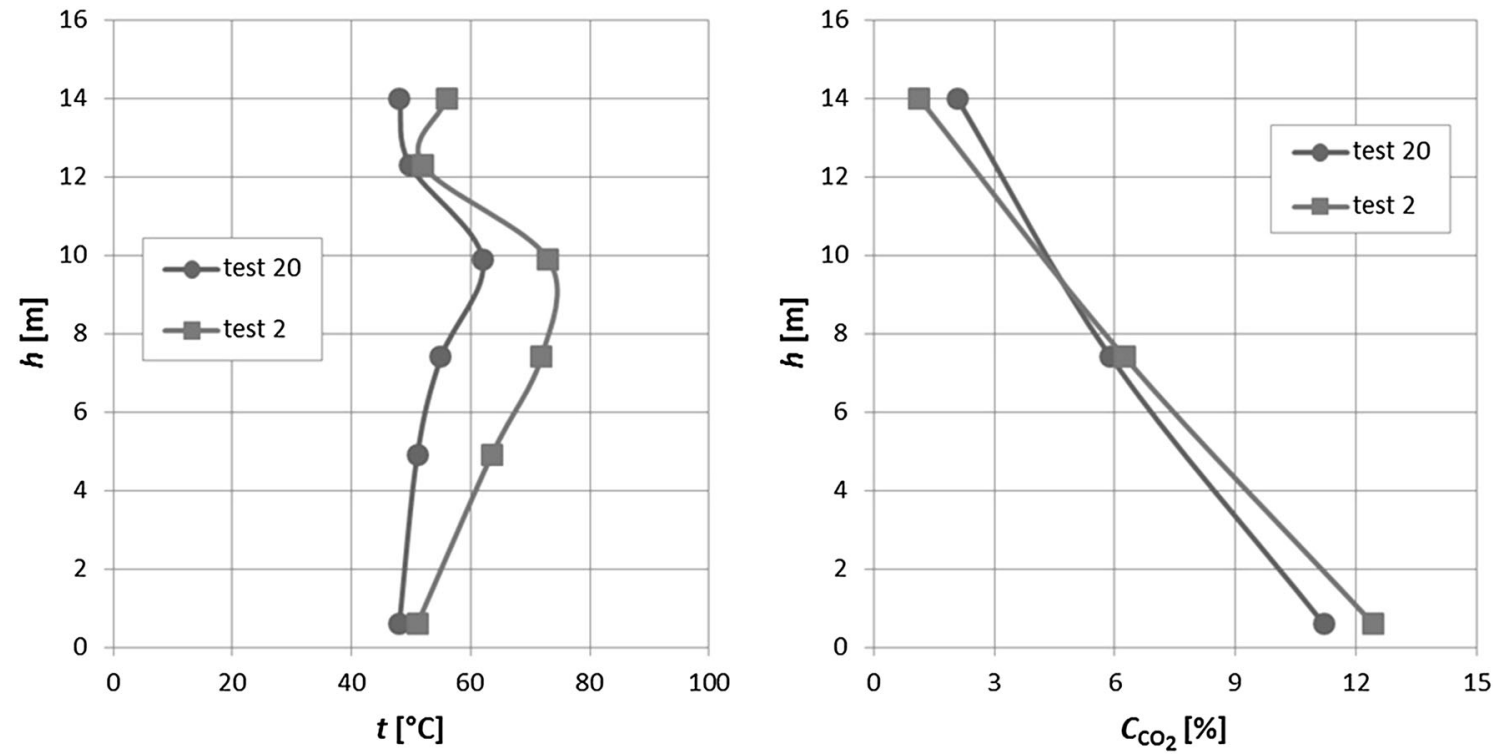

Fig. 3 Temperature and $\mathrm{CO}_{2}$ concentration profiles in the absorber column. The lines serve only to join the data
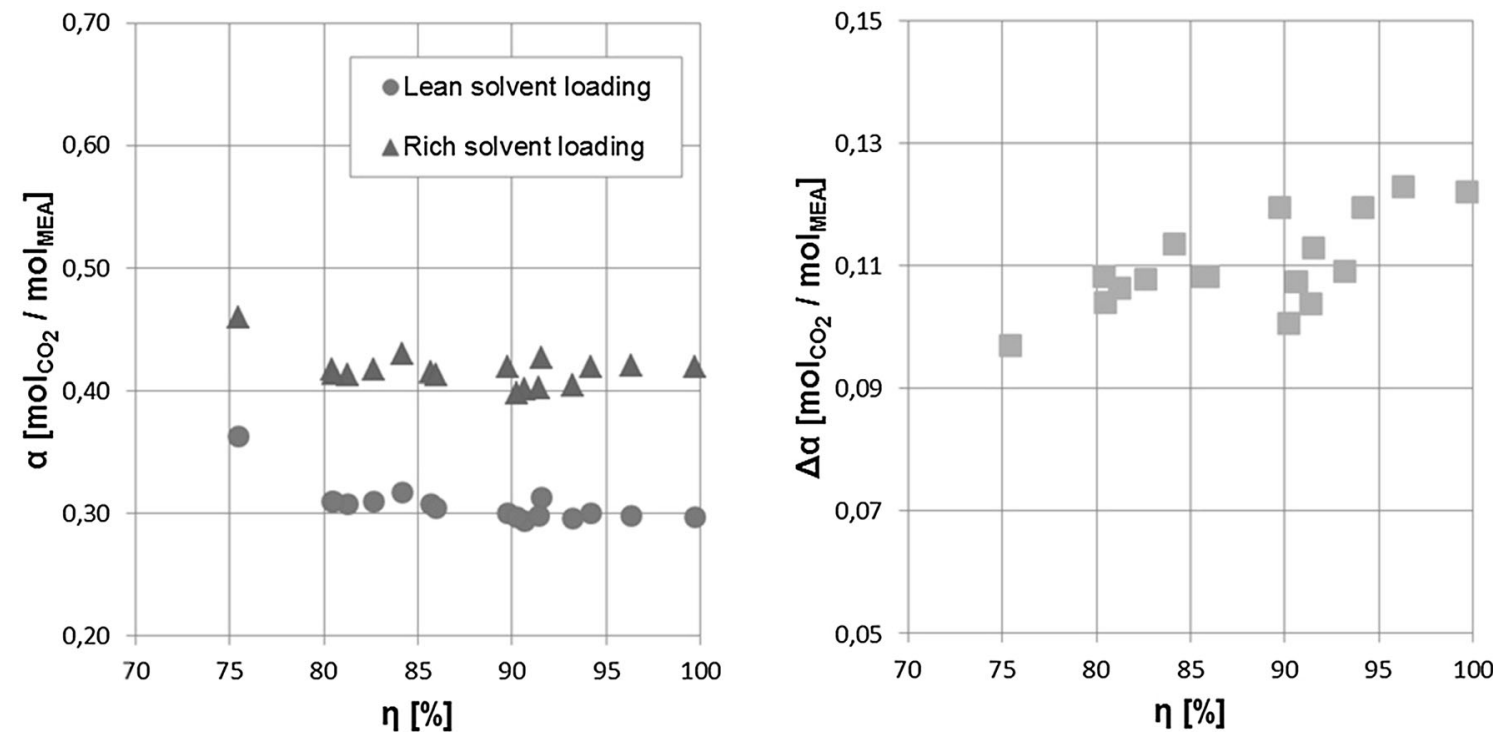

Fig. 4 Solvent loading and cyclic capacity as a function of the $\mathrm{CO}_{2}$ recovery 


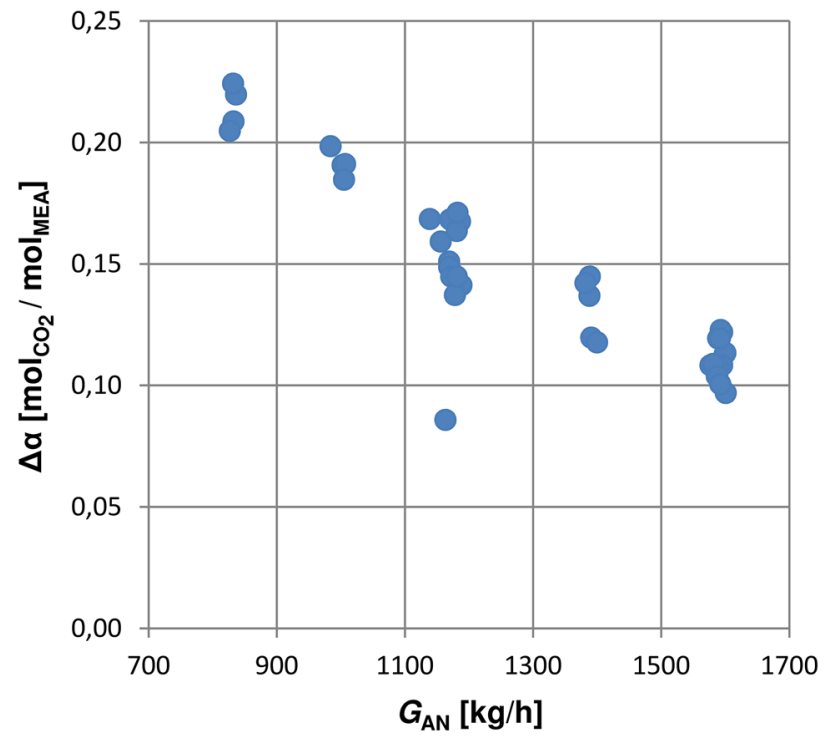

Fig. 5 Solvent loading change as a function of the lean solvent flow rate

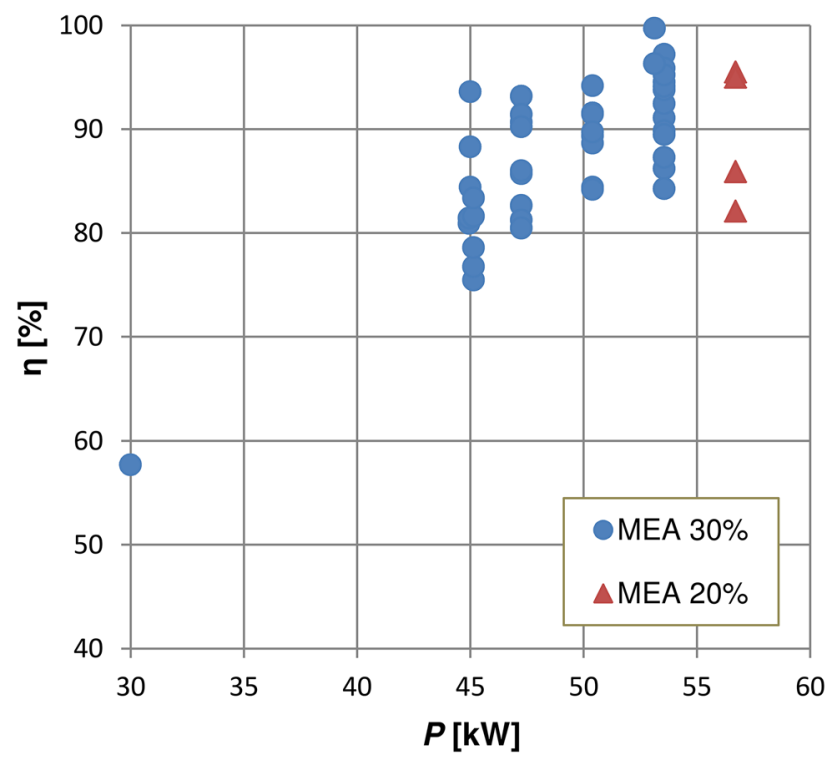

Fig. $6 \mathrm{CO}_{2}$ recovery as a function of the power delivered to the stripper

compares the efficiency of the pilot plant depending on the absorber pressure $p_{\mathrm{ABS}}$ (test $37-\mathrm{p}_{\mathrm{ABS}}=25 \mathrm{kPa}$, test $38-\mathrm{p}_{\mathrm{ABS}}=30 \mathrm{kPa}$, test $39-\mathrm{p}_{\mathrm{ABS}}=35 \mathrm{kPa}$, gauge pressures). The other parameters during this set of experiments (solvent rate, gas flow rate, and stripper duty) were maintained constant. It could be observed that increasing the absorber pressure was favorable for the $\mathrm{CO}_{2}$ capture rate and regeneration energy demand; however, the increase in the absorber pressure was achieved by higher blower duty (Neveux et al. 2013). The compression of the flue gas had a

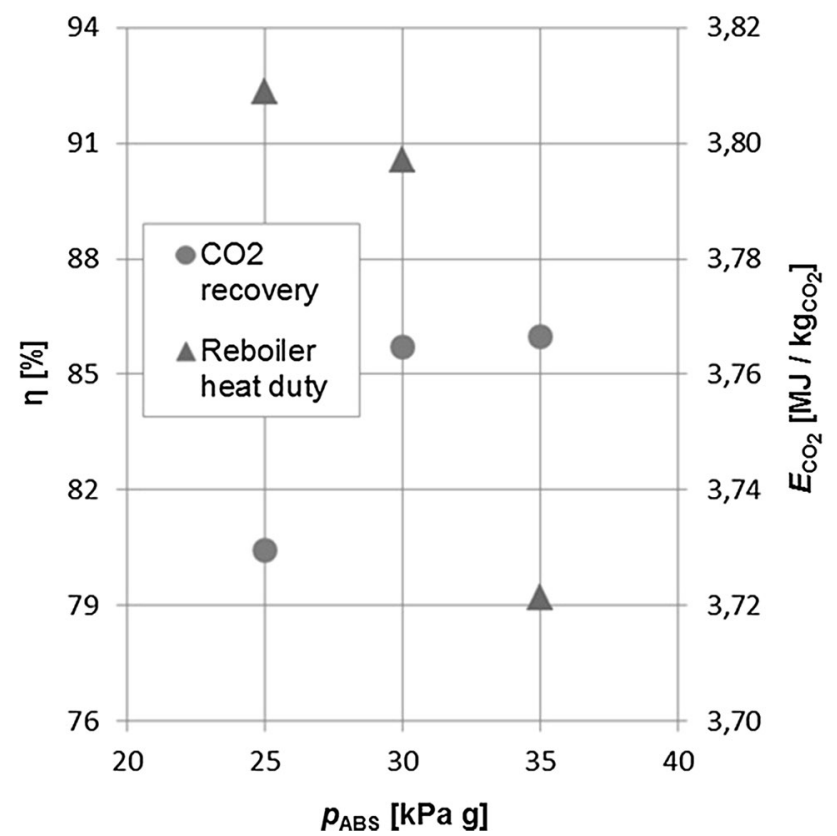

Fig. 7 Influence of the absorber pressure on the $\mathrm{CO}_{2}$ recovery and on the regeneration energy demand

serious cost; therefore, increasing the absorber pressure too much would be unreasonable.

\section{Process energy demand}

Despite the high energy demand, the post-combustion amine-based process is the most promising solution for carbon capture from coal-fired power plants. It is said that typical power plant designs with MEA will reduce power plant output by 25-35\% (Chen and Rochelle 2011). Because most of the energy is used in the stripper, it is important to reduce the required amount for this piece of equipment.

Comparing the energy demand of the amine-based carbon capture process is complex because the numbers strongly depend on the solvent used or on the specific plant design. To provide an orientation, the literature data on energy demand are presented in Table 4; however, the numbers should not be compared directly.

Figure 8 presents the regeneration energy demand for numerous tests as a function of the $\mathrm{CO}_{2}$ concentration in the flue gas. The approximate comparison with the literature data confirmed the correct operation of the pilot plant. The majority of the tests achieved a regeneration energy demand well below $4.0 \mathrm{MJ} / \mathrm{kg}_{\mathrm{CO}_{2}}$, which was promising for future optimization. It is worth mentioning that such energy demand results were achieved for the standard process flow sheet (no streams split and with internal heat exchange in the stripper) and a basic solvent (30\% MEA). 
Table 4 Literature data on the energy demand of amine-based carbon capture processes (Abu-Zahra et al. 2007)

\begin{tabular}{|c|c|c|c|}
\hline Solvent & Supplier & $\begin{array}{l}\text { Specific energy demand } \\
\left(\mathrm{MJ} / \mathrm{kg}_{\mathrm{CO}_{2}}\right)\end{array}$ & Source \\
\hline $\begin{array}{l}\text { Fluor Econ-amine } \mathrm{FG}^{\mathrm{SM}} \\
(\sim 20 \% \text { wt MEA })\end{array}$ & Fluor & 4.2 & (Chapel et al. 1999) \\
\hline $\begin{array}{l}\text { Fluor Econ-amine } \mathrm{FG}^{\mathrm{SM}} \text { plus } \\
(\sim 30 \% \text { wt MEA with proprietary additives })\end{array}$ & Fluor & 2.9 & (Reddy and Gilmartin 2011) \\
\hline MEA & Dong energy Esbjerg & 3.7 & (Knudsen et al. 2009) \\
\hline MEA & $\begin{array}{l}\text { Mitsubishi heavy } \\
\text { industries/Kansai electric }\end{array}$ & 3.7 & (Mimura et al. 1997) \\
\hline KS-solvent (hindered amine) & $\begin{array}{l}\text { Mitsubishi heavy } \\
\text { industries/Kansai electric }\end{array}$ & 3.0 & (Mimura et al. 1997) \\
\hline Siemens AAS (amino acid salt) & Siemens/E.ON & 2.7 & (Jockenhoevel et al. 2010) \\
\hline
\end{tabular}

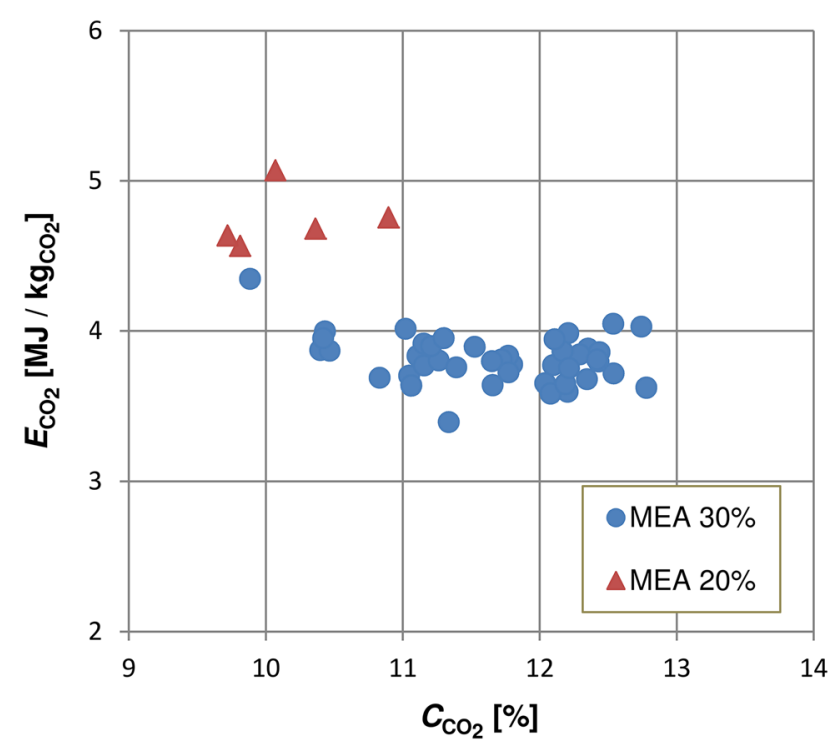

Fig. 8 Regeneration energy demand as a function of the $\mathrm{CO}_{2}$ concentration in the flue gases

Further reduction is expected after the introduction of a new solvent or for an advanced process flow sheet.

It must be noted that the process energy demand summarized in Table 3 is given as the net value, i.e., without ambient heat loss. The value of the reboiler heat duty including heat loss (gross value) was approximately $10 \%$ higher.

\section{Conclusions}

This present paper reports on the initial operation and presents general results achieved during the first pilot plant tests. The pilot plant campaigns successfully demonstrated reliable operation, allowing the removal of over $19,000 \mathrm{~kg}$ of $\mathrm{CO}_{2}$ from flue gases at the Łaziska Power Plant in Łaziska Górne, Poland.

The energy requirement for the MEA process was found to be well below $4.0 \mathrm{MJ} / \mathrm{kg}_{\mathrm{CO}_{2}}$, which was satisfactory considering that only the results of the process flow sheet without stream splitting were presented. The completed campaigns could become a baseline for extended comparisons.

In the coming years, the pilot plant will be used to evaluate advanced process innovations such as split streams of solvent. In addition to the technological modifications, the performance of novel solvents developed in the project (Wilk et al. 2013b; Śpiewak et al. 2015) will be evaluated.

Acknowledgments The results presented in this paper were obtained during research co-financed by the National Centre of Research and Development in the framework of Contract SP/E/1/ 67484/10 - Strategic Research Program-Advanced technologies for energy generation: Development of a technology for highly efficient zero-emission coal-fired power units integrated with $\mathrm{CO}_{2}$ capture.

Open Access This article is distributed under the terms of the Creative Commons Attribution 4.0 International License (http://creativecommons.org/licenses/by/4.0/), which permits unrestricted use, distribution, and reproduction in any medium, provided you give appropriate credit to the original author(s) and the source, provide a link to the Creative Commons license, and indicate if changes were made.

\section{References}

Abu-Zahra MRM, Schneiders LHJ, Niederer JPM et al (2007) CO2 capture from power plants: part I. A parametric study of the technical performance based on monoethanolamine. Int J Greenh Gas Control 1:37-46. doi:10.1016/S1750-5836(06)00007-7

Bandyopadhyay A (2010) Amine versus ammonia absorption of CO2 as a measure of reducing GHG emission: a critical analysis. Clean Technol Environ Policy 13:269-294. doi:10.1007/s10098010-0299-z 
Chapel DG, Mariz CL, Ernest J (1999) Recovery of $\mathrm{CO}_{2}$ from flue gases: commercial trends. In Canadian society of chemical engineers annual meeting

Chen X, Rochelle GT (2011) Aqueous piperazine derivatives for $\mathrm{CO}_{2}$ capture: accurate screening by a wetted wall column. Chem Eng Res Des 89:1693-1710. doi:10.1016/j.cherd.2011.04.002

Cousins A, Wardhaugh LT, Feron PHM (2011) A survey of process flow sheet modifications for energy efficient $\mathrm{CO}_{2}$ capture from flue gases using chemical absorption. Int J Greenh Gas Control 5:605-619. doi:10.1016/j.ijggc.2011.01.002

Damartzis T, Papadopoulos AI, Seferlis P (2014) Optimum synthesis of solvent-based post-combustion $\mathrm{CO}_{2}$ capture flowsheets through a generalized modeling framework. Clean Technol Environ Policy 16:1363-1380. doi:10.1007/s10098-014-0747-2

Hartono A, Saleem F, Arshad MW et al (2013) Binary and ternary VLE of the 2-(diethylamino)-ethanol (DEEA)/3-(methylamino)propylamine (MAPA)/water system. Chem Eng Sci 101:401-411. doi:10.1016/j.ces.2013.06.052

Hartono A, Mba EO, Svendsen HF (2014) Physical properties of partially $\mathrm{CO}_{2}$ loaded aqueous monoethanolamine (MEA). J Chem Eng Data 59:1808-1816. doi:10.1021/je401081e

Jockenhoevel T, Schneider R, Rode H (2010) Validation of a secondgeneration postcombustion capture technology-results from POSTCAP pilot plant operation. In PowerGen Europe

Kim I, Jens CM, Grimstvedt A, Svendsen HF (2011) Thermodynamics of protonation of amines in aqueous solutions at elevated temperatures. J Chem Thermodyn 43:1754-1762. doi:10.1016/j. jet.2011.06.004

Knudsen JN, Jensen JN, Vilhelmsen P-J, Biede O (2009) Experience with $\mathrm{CO} 2$ capture from coal flue gas in pilot-scale: testing of different amine solvents. Energy Procedia 1:783-790. doi:10. 1016/j.egypro.2009.01.104

Krótki A, Tatarczuk A, Więcław-Solny L et al (2014) $\mathrm{CO}_{2}$ amine absorption as an opportunity to reduce emissions from domestic coal-fired power plants. Przem Chem 93:2241-2245. doi:10. 12916/przemchem.2014.2241

Kvamsdal HM, Rochelle GT (2008) Effects of the temperature bulge in $\mathrm{CO}_{2}$ absorption from flue gas by aqueous monoethanolamine. Ind Eng Chem Res 47:867-875. doi:10.1021/ie061651s

Mangalapally HP, Notz R, Hoch S et al (2009) Pilot plant experimental studies of post combustion $\mathrm{CO}_{2}$ capture by reactive absorption with MEA and new solvents. Energy Procedia 1:963-970. doi:10.1016/j.egypro.2009.01.128

Mangalapally HP, Notz R, Asprion N et al (2012) Pilot plant study of four new solvents for post combustion carbon dioxide capture by reactive absorption and comparison to MEA. Int $\mathrm{J}$ Greenh Gas Control 8:205-216
Maroušek J, Hašková S, Zeman R et al (2014) Processing of residues from biogas plants for energy purposes. Clean Technol Environ Policy 17:797-801. doi:10.1007/s10098-014-0866-9

Meldon JH (2011) Amine screening for flue gas CO2 capture at coalfired power plants: should the heat of desorption be high, low or in between? Curr Opin Chem Eng 1:55-63. doi:10.1016/j.coche. 2011.08.006

Mimura T, Simayoshi H, Suda T et al (1997) Development of energy saving technology for flue gas carbon dioxide recovery in power plant by chemical absorption method and steam system. Energy Convers Manag 38(Supplement):S57-S62. doi:10.1016/S01968904(96)00246-4

Neveux T, Le Moullec Y, Corriou JP, Favre E (2013) Energy performance of $\mathrm{CO} 2$ capture processes: interaction between process design and solvent. Chem Eng Trans 35:337-342

Reddy S, Johnson D, Gilmartin J (2008) Fluor's econamine FG plus SM technology for $\mathrm{CO}_{2}$ capture at coal-fired power plants. In Power plant air pollutant control "mega" symposium

Skorek-Osikowska A, Kotowicz J, Janusz-Szymańska K (2012) Comparison of the energy intensity of the selected $\mathrm{CO}_{2}$-capture methods applied in the ultra-supercritical coal power plants. Energy Fuels 26:6509-6517. doi:10.1021/ef201687d

Śpiewak D, Krótki A, Spietz T et al (2015) PDU-scale experimental results of $\mathrm{CO}_{2}$ removal with AMP/PZ solvent. Chem Process Eng 36:39-48. doi:10.1515/cpe-2015-0003

Stec M, Tatarczuk A, Więcław-Solny L et al (2015) Pilot plant results for advanced $\mathrm{CO} 2$ capture process using amine scrubbing at the Jaworzno II power plant in Poland. Fuel 151:50-56. doi:10.1016/ j.fuel.2015.01.014

Szczypiński T, Tatarczuk A, Grudnik K (2013) Optimization of amine-based $\mathrm{CO}_{2}$ capture from flue gas by flowsheet modification. Przem Chem 92:106-110

Tatarczuk A, Ściążko M, Stec M et al (2013) Carbon capture, towards comprehensive knowledge-our common objective. Chem Int 67:897-902

Wilk A, Więcław-Solny L, Śpiewak D, Spietz T (2013a) Laboratory research on optimal operating conditions of $\mathrm{CO} 2$ separation plant treating flue gases with high $\mathrm{CO} 2$ content. Polityka Energ $16: 217-227$

Wilk A, Więcław-Solny L, Tatarczuk A et al (2013b) Effect of composition of absorption solution on carbon dioxide removal efficiency. Przem Chem 92:120-125

Zhou S, Wang S, Sun C, Chen C (2013) SO2 effect on degradation of MEA and some other amines. Energy Procedia 37:896-904. doi:10.1016/j.egypro.2013.05.184 